\title{
PREPARATION OF TEACHERS OF TECHNICALLY-ORIENTED DISCIPLINES IN THE FIELD OF EXPERIMENTAL WORK
}

\author{
Martin HAVELKA - Čestmír SERAFÍN - Jiř́i KROPÁČ
}

\begin{abstract}
The contribution deals with the conditions creating a complex educational environment in the constructivist concepts such as environment, which affects the fundamental level of the competence of the educator and makes his professional prowess. For the application of progressive teaching methods is a necessary condition for self experience in the framework of activities carried out in connection with the content of education. This objective is a part of the contents of disciplinary didactics application of the subject Teaching technical and information education at lower and upper secondary schools.
\end{abstract}

Key words: education, innovation, information and communication technology, laboratory work, technical education, the preparation of teachers, disciplinary didactics.

\section{PŘÍPRAVA UČITELŮ TECHNICKY ORIENTOVANÝCH PŘEDMĚTŮ V OBLASTI EXPERIMENTÁLNÍ PRÁCE}

Resumé: Př́ispěvek se zabývá podmínkami vytváření komplexního edukačního prostředí v konstruktivistickém pojetí jako prostředí, jež zásadní mírou ovlivňuje kompetence pedagoga a podmiňuje jeho profesní zdatnost. Pro aplikaci progresivních výukových metod je nezbytnou podmínkou vlastní prožití v rámci činností prováděných v souvislosti s obsahem vzdělávání. Tento cíl je součástí náplně aplikační části oborové didaktiky oboru Učitelství technické a informační výchovy pro 2. stupeň ZŠ a S ̌́.

Klíčová slova: inovace, informační a komunikační technologie, laboratorní práce, technická výchova, př́prava učitelů, oborová didaktika.

\section{1 Úvod}

Východiskem pro změny ve vyučovacím procesu je v současnosti proaktivní př́stup ke vzdělávání. Výukové aktivity jsou dnes v řadě př́padů podporované informačními a komunikačními technologiemi. Nejen v technicky orientovaných disciplínách jsou tyto aktivity součástí inovativních metod aplikovaných ve výuce. $V$ informační společnosti je jedním z aktuálních požadavků rozvíjení obecného pojetí informatické výchovy napríč všemi oblastmi poznání. Tomuto pojetí je třeba adekvátně přizpůsobovat i modernizační trendy v prrípravě učitelů, jakožto základních nositelů a zprostředkovatelů poznání mladé generace. V tomto pojetí je také prristupováno k inovacím $\mathrm{v}$ př́ípravě učitelů obecně technických disciplín realizovaných na PdF UP.

\section{Konstruktivistický př́ístup}

Soudobá pregraduální př́iprava učitelů technicky orientovaných disciplín ve všeobecném pojetí je realizována $\mathrm{v}$ převážné míre $\mathrm{v} t \mathrm{tz}$. konstruktivistickém pojetí založeném na motivované činnosti studentů učitelství směrem $\mathrm{k}$ rozvoji jejich myšlení a výchovy $\mathrm{k}$ technické tvořivosti. Je předpoklad, že ve své vlastní edukační praxi budou budoucí pedagogové stejně přistupovat ke svým žákům a budou rovněž vycházet z předpokladu, že stejně jako oni i jejich žáci si v procesu učení nové skutečnosti budou aktivně interpretovat na základě porozumění toho, co již dřive poznali. Tento proces konstruování poznatkových struktur tedy využívá dosavadních mentálních struktur, prekonceptů. Dovozujeme tím, že jsou tak doceňovány především individuální vlastnosti osobnosti jedince, které u mladé generace mají velký význam.

Učivo lze pak ve výše uvedeném konceptu vnímat jako kvalitní, umožní-li samostatné, tvořivé, rozvíjející činnosti, kdy pedagog vytváří autentické, komplexní, životu či profesi blízké, sociálně podmíněné situace. Výuka je tak zaměřena na konstrukci nových poznatků podmíněnou vhodnými prameny poznání, 
respektující individuální vlastnosti a předpoklady včetně tempa vlastní práce. Chyby v učení jsou využívány $\mathrm{k}$ optimalizaci procesu vzdělávání i výsledků učení.

V tomto kontextu je důležitou otázkou „porozumění“ a procesy jeho vzniku. Phillips (1) postihuje trri základní role jedince $\mathrm{v}$ procesu učení:

1. Aktivní role: poznání a porozumění vyžaduje aktivitu učícího se namísto pasivní role př́jemce poznatků.

2. Společenská role: poznatky nebudujeme pouze individuálně, ale $\mathrm{v}$ dialogu s ostatními.

3. Kreativní role: poznání a porozumění je tvořeno a přetvářeno. Učitelé vedou žáky $\mathrm{k}$ tomu, aby aktivně rekonstruovali své původní představy $\mathrm{v}$ interakci s ostatními.

Lze samozřejmě vysledovat více typů konstruktivistického př́stupu $\mathrm{k}$ řešení určité oblasti (personální, sociální, vývojový, postmoderní, informačně-procesní, kybernetický apod.), což je dáno také úhlem pohledu jednotlivých odborníků, kteří se uvedenou problematikou zabývají (2). V zásadě se ale vždy jedná o to, kam zasadit poznání $\mathrm{v}$ rovině mezi individuální konstrukcí a sociální interakcí.

Za základní pilíre konstruktivistického pojetí učení se lze pokládat následující základní teze (3):

1. Poznání je „ve fyzické podobě“ konstruováno učícím se subjektem, a to na základě jeho aktivního učení.

2. Poznání je symbolicky konstruováno učícím se subjektem, a to na základě vytváření pojetí (modelů, schémat, zapojení) prostřednictvím jeho vlastního jednání.

3. Poznání je společensky konstruováno učícím se subjektem, a to na základě sdělování pochopeného smyslu ostatním.

4. Poznání je teoreticky konstruováno učícím se subjektem tak, že se pokouší vysvětlit věci, kterým zcela nerozumí.

Vycházíme-li z výše uvedeného dle teorií konstruktivismu a dle teorií konstruktivismu blízkých, je tedy možno porozumění chápat jako interpretaci nových informací ve světle dosavadních znalostí (4) a rovněž jako proces, při němž jedinec mentálně konstruuje význam a smysl toho, co o tom ví a co vnímá (5). Je tedy zdůrazněn význam aktivního subjektu konstruujícího znalosti v závislosti na prostředí i jeho zkušenostech. Porozumění tedy znamená přepracování a rozšíření myšlenkového konstruktu $s$ ohledem na již zmíněné tzv. prekoncepty, tedy na stávající zkušenosti, znalosti, př́stupy a mentální struktury (6).

Výuka může být úspěšně realizována jen $\mathrm{v}$ podmínkách vytvoření komplexního edukačního prostředí, prostředí, v němž se žák či student chce a může učit tak, aby byl úspěšný, aby jej dosažené výsledky motivovaly pro další vzdělávání. Tvorba komplexního edukačního prostředí je jednou ze zásadních kompetencí pedagoga podmiňujících a vyjadřujících jeho profesní zdatnost.

V oblasti vzdělávání učitelů obecně technicky orientovaných predmětů je proto nezbytná jejich prŕíprava založená na synergii technických (včetně oblasti informačních technologií) a pedagogickopsychologických disciplín. Tato prŕíprava, je-li spojena $\mathrm{s}$ tvưrčí experimentální prací studenta, umožňuje optimalizovat dosahování jeho didaktických znalostí obsahu výuky (7).

Klademe-li důraz na mezipředmětové vztahy a integrovanou podobu výuky i u technicky orientovaných předmětů, pak je pochopitelné, že tyto oblasti musí vycházet z úzké spolupráce pedagogů daných i př́buzných předmětů a na tuto spolupráci musí být adekvátním způsobem připravováni budoucí učitelé. Otázka ale zní i dále - $\mathrm{s}$ jakými vůbec vědomostmi a představami vstupují žáci do př́islušného ročníku školy, jaké jsou jejich prekoncepty a jak tedy ve vzájemné spolupráci učitelů lze vůbec vytvářet odpovídající didaktický model učiva.

Učitel vystupuje v procesu učení jako facilitátor vytvářející vhodné podmínky pro individuální (individualizované) učení žáka. Role učitele jako aktivizačního prvku se do jisté míry přesunuje na samotného žáka. Přesto je role učitele stále nezastupitelná: učitel navozuje problémové situace tak, aby je žáci aktivně uchopili, vyjádřili vlastním chápáním a následně tvořili otázky, stanovovali si cíle atd. Úlohou učitele je tedy vlastně vhodné uspořádání „prostředí a klimatu“ pro učení (8). Gagnon, Collay (3) navrhují následující schéma konstruktivistického učení:

- prostřednictvím situace (situation),

- shromažd’ování (groupings),

- překlenutí (bridge),

- dotazování (questions),

- znázornění (exhibit),

- reflexe (reflection).

Konstruktivismus tedy zdůrazñuje proces konstruování poznatků jedincem a jeho aktivní 
roli při této konstrukci poznání prostřednictvím vlastní činnosti, aktivity, ale také sdílení tohoto poznání s ostatními. Poukazuje na to, že nové skutečnosti interpretujeme ve světle předchozího porozumění vzniklého $\mathrm{z}$ dřivějších zkušeností. Tím se vytváríi schéma umožňující chápání a zařazení nových poznatků do stávajících či transformovaných poznatkových struktur. Pokud se však nové poznatky nedostanou do styku s tímto vlastním, již vytvořeným pojetím, nedojde k potřebnému porozumění a žádoucímu procesu učení (9).

\section{Specifika zaměření experimentální práce $v$ technicky orientovaných předmětech}

Rozvíjení technického myšlení je základním úkolem výuky technických předmětů bez ohledu na jejich bližší zacílení. Významný pojem technické myšlení analyzoval polský psycholog E. Franus, jeho práci prezentoval a v našich podmínkách a v tehdejším Československu rozvíjel I. Krušpán. Ten do slovenštiny přeložil charakteristiku pojmu technické myšlení (10), vytvořenou E. Franusem: „Technické myslenie je proces odrážania a využivania prírodných zákonov a technických princípov $v$ technických výtvoroch avtechnologických procesoch." Uvedená charakteristika pojmu přesně vyjadřuje dvě související a E. Franusem popsané stránky technického myšlení - tedy stránku procesů poznávacích, mají charakter převážně analytický, a stránku procesů kreativních či procesů konstruování, v nichž převažuje syntéza, viz mj. $(11$, s. 141 - 144).

Uvedené dvě stránky technického myšlení by měly být respektovány i při koncipování experimentální činnosti pro technické předměty, ta by je měla „uceleně“ zahrnovat. Procesy poznávací mají tedy i při experimentování v technických předmětech základní logiku a zaměření obdobné jako $v$ předmětech přírodovědných, musejí však respektovat široký kontext souvislostí společenských (ekonomických, psychologických atp.), prírodních a pochopitelně také technických (ztížena je tedy abstrakce). Podnětné ale i pro technické předměty jsou současné trendy v pojetí experimentování $\mathrm{v}$ přírodovědných předmětech. Zde se výrazně projevuje snaha po uplatnění badatelského př́stupu, takto orientované statě publikovali mj. T. Janík a I. Stuchlíková, D. Nezvalová či M. Papáček. Jde nesporně o snahu navazující na aplikaci konstruktivistického pojetí do výuky. Badatelsky orientované experimentování staví žáka do role „vědců či badatelư“. Dle D. Nezvalové (12) žáci při badatelsky orientovaném vyučování či experimentování, na základě situací vytvořených učitelem: - si kladou badatelsky orientované otázky, - hledají důkazy, - formují objasnění na základě důkazů, - vyhodnocují objasnění s možností využití alternativ v objasňování, komunikují a ověřují objasnění.

Uvedené plně platí i pro experimentování $\mathrm{v}$ technických předmětech. To by však nebylo úplné, podporovalo by pouze poznávací činnost zaměřenou na objevování zde zpravidla základních, všeobecných technických souvislostí a vztahů. Duševní procesy kreativní či konstruování, které dvoří druhou stránku technického myšlení, jsou i při experimentování spojeny s konkrétnějšími situacemi, činnostmi, výstupy či produkty. Jde tedy o aplikaci a syntézu nabytého poznání do „nové kvality řešení“ (alespoň z hlediska žáka) a jeho experimentální ověření. Zde ovšem by situace měly adekvátně zahrnovat etapy života techniky, jsou to: rozpoznání potřeby, projektování, konstruování, programování (např. technologické zajištění výroby), vytváření, využívání a likvidace (13, s. 51-53).

Zahrnutí vlastní poznávací činnosti žáka a rovněž procesů kreace, jakožto řešení výukové situace spočívající v uspokojení oprávněné potřeby individua či skupiny, v celé ššŕi vzniku, užívání a likvidace techniky, to vše je v obecném smyslu předmětem výuky technických předmětů a mělo by být podporováno experimentální činností žáků.

\section{Praktická realizace}

Učitel v moderním pojetí - facilitátor utváří vlastní uspořádání třídy, její prostředí či klima tím, že „staví mosty“ mezi tím, co už žáci vědí a co se mají teprve naučit. Otázky a vzájemná diskuse napomáhají žákům ukázat, jak danou situaci pochopili a co se z ní naučili. Pomocí reflexe si pak mohou uvědomit a učinit explicitním celý svůj proces učení - jak se změnila jejich původní představa, co se naučili, a co by se ještě chtěli naučit.

Chceme-li tedy inovovat výukový proces, pak $\mathrm{v}$ praktické realizaci $\mathrm{v}$ daném edukačním prostředí je nutné vycházet z:

- teorie pedagogického konstruktivismu, jež doceňuje zkušenost a činnost subjektu, nebot' 
se opírá o motivovanou činnost zaměřenou $\mathrm{k}$ rozvoji myšlení i tvořivosti. Pro př́pravu učitelů tím konstruktivismus také zdůvodňuje všeobecnou zkušenost, že učitel více použivá ty způsoby činnosti, které sám prožil, než ty, s nimiž byl jen „teoreticky seznámen“.

moderně zpracovaného učiva na interaktivní bázi - uspořádání struktury obsahu výuky jak po procesní stránce včetně její organizace, tak souvisejícími materiálními podmínkami. Součástí výuky prakticky orientovaných disciplín se tak musí stát vytváření autentických, komplexních, životu či profesi blízkých situací, při nichž je rozvíjena i schopnost spolupráce.

V praktické podobě je takto pojaté vyučování náročné na vytváření podmínek pro optimální poznávání, také proto musí být budoucí učitel připravován $\mathrm{v}$ obdobném kontextu jako jeho budoucí žáci. Proto pro konstruktivisticky pojatou výuku technických a odborných předmětů lze uvést:

praktická a laboratorní výuka, experimenty, projekty, řešení úloh atp. mohou vytvářet předpoklady pro realizaci konstruktivistického pojetí. Významným faktorem je nezbytnost předchozí přípravy,

- konstruktivistické pojetí výuky je významně podporováno realizací projektové výuky nebo uplatňováním prvků projektové výuky. Součástí inovace předmětů spojených s laboratorní prací jsou tedy př́padové studie zahrnující samostatné plánování, vymezování požadavků na výsledek a jeho projektování, konstruování, realizaci a rovněž hodnocení z hlediska výsledku činnosti,

- praktická, laboratorní výuka má význam z hlediska učitelovy schopnosti komunikace ve výuce. $\mathrm{V}$ technických oborech jsou používány hojně také pojmy „nedefinované“, tzv. předdefinitorní formy vyjádření. Tyto pojmy jsou založeny na poznání typických projevů a vlastností, které jsou vlastní objektům přináležejícím do vymezovaného pojmu. Z hlediska poznávání pojmu jakožto základního kamene učitelovy komunikace se žáky má praktická, přemýšlivá činnost značný význam.

Výše uvedené tedy musí najít svoji podobu $\mathrm{v}$ reálné praxi přípravy budoucího učitele, proto komplexním cílem je inovace pracoviště $v$ konstruktivistickém pojeti prípravy. $\mathrm{Z}$ technického hlediska je kladen důraz i na propojení informačních a komunikačních technologií se soudobou praxí, která je významnou součástí prípravy učitelů i u technicky orientovaných disciplín. V prostředí učitelské př́pravy je tato odborná stránka vždy spojována se stránkou didaktickou a metodologickou vytvořením adekvátního edukačního prostředí.

Jako vhodné propojení výše uvedeného pojetí s praxí laboratoře elektrotechniky se jeví př́stup k tzv. „,vzdálenému experimentu“ (14), (15), (16) realizovanému přes internet (souprava ISES WEB Control - programátorská stavebnice, která sestávající se $\mathrm{z}$ cca 30 appletů, serverů a ukázkových př́kladů umožňující on-line sledování, ř́zení a měření úloh) - viz obr. 1 a 2 . Systém je založen na serverové softwarové části běžící na standardním WEB serverovém prostoru Windows typu. Na serverovém WEB prostoru jsou vzdálené úlohy realizovány skoro jako standardní "HTML" stránky, obsahující Java applety, které umožní komunikaci s měřící aparaturou. Serverový software kromě HTML stránek s applety obsahuje spuštěné aplikace, které zprostředkují komunikace s hardwarem. $\mathrm{Na}$ serveru běži kromě již zmíněného libovolného standardního WEB serveru, další serverové aplikace - ImageServer pro podporu WEB kamer, MeasureServer pro ovládání hardware, HTTPRelay pro připojování uživatelů s omezenými prístupy. Samozřejmostí je připojení nezbytné hardwarové části - např. měřící aparatury.

Vzdálené experimenty jsou moderním nástrojem edukačního prostř̌edí realizujícím reálné laboratorní experimenty ovládané prostřednictvím internetu tzv. on-line. Tyto experimenty mají oproti klasickým školním experimentům $\mathrm{v}$ tradičních laboratořích několik vcelku podstatných výhod (17):

- volný prŕstup do „vzdálené“ laboratoře (kdykoliv, odkudkoliv),

- nepotřebnost pomůcek, měřicích přístrojů a další techniky,

- možnost experiment mnohokrát opakovat,

- práce $\mathrm{s}$ reálnými měřicími př́stroji, s reálnými daty,

- rychlé grafické zpracování dat,

- žádná rizika, nehrozí nebezpečí úrazu,

- lze využít pro domácí př́pravu a distanční výuku. 


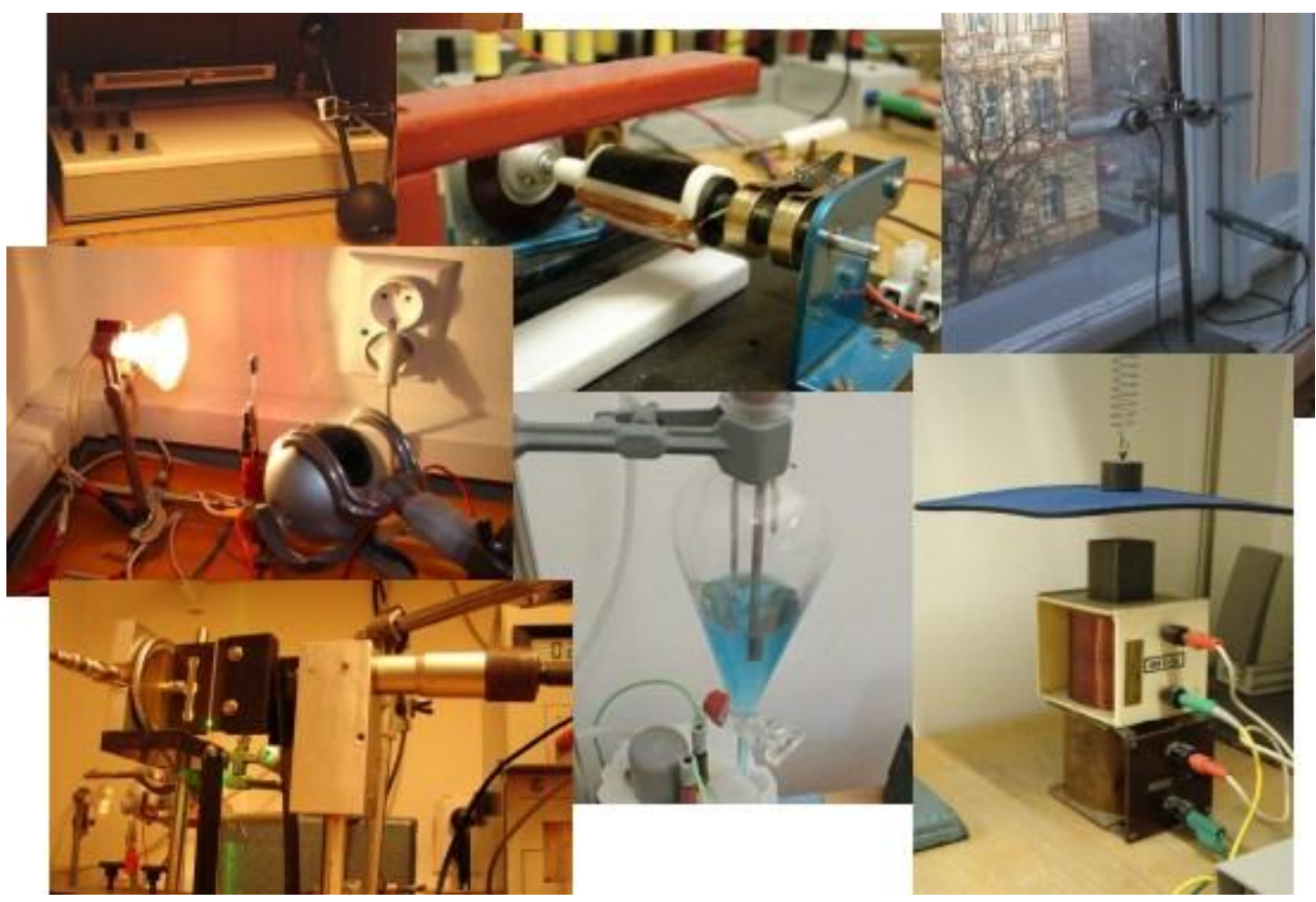

Obr. 1 Ukázky tzv. „,vzdálených laboratoříi“

(http://www.ises.info/index.php/cs/laboratory)

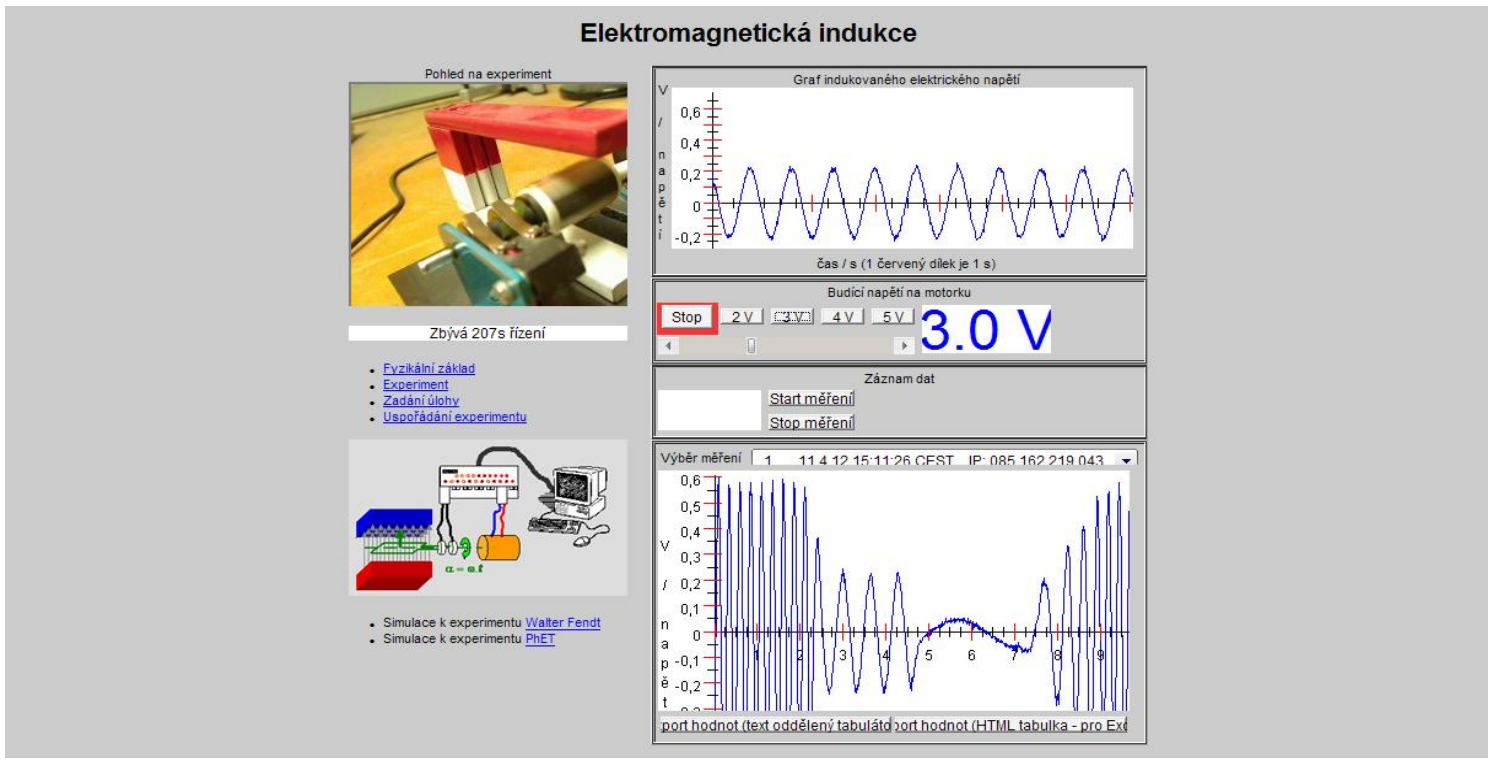

Obr.2 Úloha: Elektromagnetická indukce (http://kdt-20.karlov.mff.cuni.cz/ovladani_2.html)

\section{Závěr}

Považujeme za významné v souladu s proměnami současné školy, směřujícími mimo jiné k činnostní a zkušenostní orientaci ve výuce, posilovat výše uvedené pojetí prípravy studentů učitelství obecně technických předmětů jejím obohacením o konstruktivistické prvky a jejich praktickou aplikaci. V procesu pregraduální př́ípravy učitelů technické a informační výchovy je sledován cíl efektivní př́pravy studentů na jejich budoucí pedagogickou praxi jak po stránce odborné, tak po stránce oborově didaktické. 
Východiskem ve změnách pojetí výuky oborové didaktiky technické a informační výchovy je kritická analýza stávajícího pojetí výuky spojená se zhodnocením úrovně a kvality dosahovaných kompetencí studentů. $\mathrm{Na}$ základě toho jsou realizovány př́slušné inovace oborové didaktiky $\mathrm{v}$ rovině teoretické, které mají príśslušný přesah i do roviny aplikační a projevují se současně i ve sféře využívaného materiálního zabezpečení a souvisejícího souboru kompetencí učitele potřebných pro jejich smysluplné začlenění do plánované výuky. Důležitou a doposud částečně opomíjenou otázkou je zde oblast aplikace vzdáleného experimentu ve výuce obecně technického a odborného technického předmětu. Tato otázka stala rovněž klíčovou v rámci řešení projektu „Inovace prípravy učitelu techniky orientovaných disciplín voblasti experimentální práce“.

\section{Literatura}

[1] PHILLIPS, D. C. The good, the bad, and the ugly: The many faces of constructivism. Educational Researcher 1995, č. 24 (7), s. 5-12

[2] ERNEST, P. The one and the many. In STEFFE, L., GALE, J. (Eds.) Constructivism in education. New Jersey: Lawrence Erlbaum Associates, Inc., 1995.

[3] GAGNON, G. W., COLLAY, M. Constructivist Learning Design. 2005. (WWW document:

http://www.prainbow.com/cld/cldp.html).

[4] GRECMANOVÁ, H.; E. URBANOVSKÁ a P. NOVOTNÝ. Podporujeme aktivní myšleni a samostatné učení žákủ. Vyd. 1. Olomouc: Hanex, 2000, 159 s. Edukace. ISBN 80-857-8328-2.

[5] ČÁP, J. Psychologie pro učitele. Vyd. 1. Praha: Portál, 2001, 655 s. ISBN 80-717-8463-X. [6] KROPÁČ, J. a J. PLISCHKE. Porozumění technice $\mathrm{v}$ př́pravě učitelů obecně technických předmětů. In XXI. DIDMATTECH 2008: 2nd part.
[7] Eger-Komárno: Esterázy Károly College, J. Selye University, 2009, s. 199-203. ISBN 978963-9894-18-1.

[8] JANÍK, T. Možnosti rozvíjení didaktických znalostí obsahu u budoucich učitelü. Brno: Paido, 2008, 148 s. Pedagogický výzkum v teorii a praxi, s. 14. ISBN 978-807-3151-768.

[9] GRECMANOVÁ, H. Klima školy. Olomouc: Hanex, 2008. ISBN 978-80-7409-010-3.

[10] NEZVALOVÁ, D. (ed.) Konstruktivismus ajeho aplikace $v$ integrovaném pojetí prírodovédného vzdělávání. Úvodní studie. Olomouc: VUP, 2006. ISBN 80-244-1258-6

[11] KRUŠPÁN, I. Rozvíjanie technického tvorivého myslenia $\mathrm{v}$ procese technickej záujmovej činnosti. In Rozvíjanie tvorivých činností v pracovnej výchove. Banská Bystrica: Pedagogická fakulta, 1985, s. 47 - 58.

[12] FRANUS, E. The Dual Nature of Technical Thinking. In Technology as a challenge for school curricula.The Stockholm Llibrary of Curriculum Studies. Stockholm: Institut of Education Press, 2003, s. 141 - 144. ISSN 14034972. ISBN 91-7656-543-2.

[13] NEZVALOVÁ, D. aj. Inovace v prírodovédném vzdélávání. Olomouc: Univerzita Palackého, 2010. ISBN 978-80-2442540-5.

[14] FURMANEK, W. a WALAT, W. Przewodnik metodyczny dla nauczycieli technikiinformatyki. 1. wyd. Rzeszów: Wydawnictwo Oświatowe FOSZE, 2002. ISBN 83-88845-08-X. [15] LUSTIG, F. Problematika vzdálených a virtuálních laboratoří $\mathrm{v}$ distančním vzdělávání [online]. 2008 [cit. 2012-04-21]. Dostupné z: http://pf.ujep.cz/ccv-

old/ext/konference_2008/Lustig_08.pdf.

[16] SERAFÍN, Č. Virtual Electronic Construction Kits in Technical Subjects. In. Edukacija - Technika - Informatika. Rzeszow: FOSZE, 2010, ročník 1/2010, Číslo 2, s.139-144. ISSN 2080-9069. ISBN 978-83-7586-043-6. 
[17] SERAFÍN, Č. Počítačová podpora experimentu. In. Mezinárodni konference učitelu elektrotechniky SEKEL2009. Brno: 2009, str. 6467. ISBN 978-80-214-3934-4.

[18] LÁTAL, F. Výhody vzdáleně ovládaných experimentů. In. Vzdáleně ovládaná laborator [online]. 2010 [cit. 2011-04-21]. Dostupné z: http://www.ictphysics.upol.cz/remotelab/vyhody. html.

Př́íspěvek vznikl za podpory projektu FRVŠ č. 1800/2012 „Inovace prípravy učitelu techniky orientovaných disciplín v oblasti experimentální práce“.
Lektoroval: PhDr. PaedDr. Jiř́ Dostál, Ph.D.

Doc. Ing. Čestmír Serafín Dr.

Doc. PaedDr. Jiř́i Kropáč CSc.,

Mgr. Martin Havelka Ph.D.

Katedra technické a informační výchovy,

Pedagogická fakulta UP

Žižkovo nám. 5

77140 Olomouc, $\check{\mathbf{C}} \mathbf{R}$

Tel: +420 585635802, +420 585635805 ,

+420585635812

E-mail: cestmir.serafin@upol.cz, jiri.kropac@upol.cz, martin.havelka@upol.cz Www pracovišstě: www.kteiv.upol.cz 